\title{
EFFICACY OF PONAZURIL IN VITRO AND IN PREVENTING AND TREATING TOXOPLASMA GONDII INFECTIONS IN MICE
}

\author{
Author(s): Sheila M. Mitchell , Anne M. Zajac , Wendell L. Davis , and David S. Lindsay \\ Source: Journal of Parasitology, 90(3):639-642. 2004. \\ Published By: American Society of Parasitologists \\ DOI: http://dx.doi.org/10.1645/GE-250R \\ URL: http://www.bioone.org/doi/full/10.1645/GE-250R
}

BioOne (www.bioone.org) is a nonprofit, online aggregation of core research in the biological, ecological, and environmental sciences. BioOne provides a sustainable online platform for over 170 journals and books published by nonprofit societies, associations, museums, institutions, and presses.

Your use of this PDF, the BioOne Web site, and all posted and associated content indicates your acceptance of BioOne's Terms of Use, available at www.bioone.org/page/terms_of_use.

Usage of BioOne content is strictly limited to personal, educational, and non-commercial use. Commercial inquiries or rights and permissions requests should be directed to the individual publisher as copyright holder. 


\title{
EFFICACY OF PONAZURIL IN VITRO AND IN PREVENTING AND TREATING TOXOPLASMA GONDII INFECTIONS IN MICE
}

\author{
Sheila M. Mitchell, Anne M. Zajac, Wendell L. Davis ${ }^{\star}$, and David S. Lindsay $†$ \\ Center for Molecular Medicine and Infectious Diseases, Department of Biomedical Sciences and Pathobiology, Virginia-Maryland Regional \\ College of Veterinary Medicine, Virginia Tech, 1410 Prices Fork Road, Blacksburg, Virginia 24061-0342. e-mail: lindsayd@vt.edu
}

\begin{abstract}
Toxoplasma gondii is an important apicomplexan parasite of humans and other warm-blooded animals. Ponazuril is a triazine anticoccidial recently approved for use in horses in the United States. We determined that ponazuril significantly inhibited T. gondii tachyzoite production $(P<0.05)$ at 5.0, 1.0 , or $0.1 \mu \mathrm{g} / \mathrm{ml}$ in African green monkey kidney cells. We used outbred female CD-1 mice to determine the efficacy of ponazuril in preventing and treating acute toxoplasmosis. Each mouse was subcutaneously infected with 1,000 tachyzoites of the RH strain of $T$. gondii. Mice were weighed daily, and ponazuril was administered orally in a suspension. Mice given 10 or $20 \mathrm{mg} / \mathrm{kg}$ body weight ponazuril 1 day before infection and then daily for 10 days were completely protected against acute toxoplasmosis. Relapse did not occur after prophylactic treatments were stopped. Toxoplasma gondii DNA could not be detected in the brains of these mice using polymerase chain reaction (PCR). One hundred percent of mice treated with 10 or $20 \mathrm{mg} / \mathrm{kg}$ ponazuril at 3 days after infection and then daily for 10 days were protected from fatal toxoplasmosis. Sixty percent of mice treated with $10 \mathrm{mg} / \mathrm{kg}$ ponazuril at 6 days after infection and $100 \%$ of mice treated with $20 \mathrm{mg} / \mathrm{kg}$ or $50 \mathrm{mg}$ ponazuril 6 days after infection and then daily for 10 days were protected from fatal toxoplasmosis. Relapse did not occur after treatments were stopped. Toxoplasma gondii DNA was detected in the brains of some, but not all, of these mice using PCR. The results demonstrate that ponazuril is effective in preventing and treating toxoplasmosis in mice. It should be further investigated as a safe and effective treatment for this disease in animals.
\end{abstract}

Toxoplasma gondii is an important parasite of humans and other warm-blooded animals. About 1,500,000 human cases of toxoplasmosis are reported in the United States each year, and about $15 \%$ of those infected have clinical signs (Mead et al., 1999; Jones, Kruszon-Moran et al., 2001). Congenital toxoplasmosis has long been recognized because of the devastating effects it can have on the infected fetus (Jones, Lopez et al., 2001). These include hydrocephalus, blindness, and mental retardation. Congenitally infected children who are less severely infected may suffer from a variety of neurological-related aliments throughout their lives (Roberts and Frenkel, 1990). In the United States, it is estimated that $85 \%$ of women of child-bearing age are at risk for toxoplasmosis (Jones, Kruszon-Moran et al., 2001) and that up to 4,000 cases of congenital toxoplasmosis occur each year (Jones, Lopez et al., 2001). Toxoplasmic encephalitis (TE) became recognized as an acquired immunodeficiency syndrome (AIDS)-defining illness in the early 1980s, and TE is still the most important neurological component of AIDS (Luft and Chua, 2000). Toxoplasmosis is also a frequent and fatal complication in patients who receive organ transplantation (Soave, 2001). The annual economic impact of toxoplasmosis in the human population in the United States is about $\$ 7.7$ billion (Buzby and Roberts, 1996).

Ponazuril is the major metabolite of toltrazuril, a triazine anticoccidial used in the poultry industry. Ponazuril has been shown to be active against Sarcocystis neurona in vitro (Lindsay and Dubey, 2000) and in vivo (Franklin et al., 2003) and against Neospora caninum in vivo (Gottstein et al., 2001). The present study was carried out to determine the in vitro and in vivo activity of ponazuril against the RH strain of $T$. gondii.

\section{MATERIALS AND METHODS}

\section{Cell culture}

African green monkey (Cercopithecus aethiops) kidney cells (CV-1 cells, ATTC CCL-70, American Type Culture Collection, Manassas,

Received 30 September 2003; revised 17 October 2003; accepted 23 October 2003.

* Bayer HealthCare Animal Health, P.O. Box 390, Shawnee, Kansas 66201-0390.

$\dagger$ To whom correspondence should be addresed.
Virginia) were grown to confluence in $25-\mathrm{cm}^{2}$ plastic cell culture flasks in growth media that consisted of $10 \%(\mathrm{v} / \mathrm{v})$ fetal bovine serum in Roswell Park Memorial Institute 1640 medium, supplemented with 100 $\mathrm{U}$ penicillin/ $\mathrm{ml}$ and $100 \mathrm{mg}$ streptomycin $/ \mathrm{ml}$. Cell cultures were incubated at $37 \mathrm{C}$ in a humidified atmosphere containing $5 \% \mathrm{CO}_{2}$ and $95 \%$ air.

\section{Ponazuril and in vitro efficacy}

The activity of ponazuril (lot PFA101; Bayer HealthCare Animal Health, Shawnee, Kansas) was determined in a tachyzoite production (TP) assay (Lindsay and Blagburn, 1994). Ponazuril was dissolved in dimethyl sulfoxide (DMSO) to make a stock solution of $1 \mathrm{mg} / \mathrm{ml}$. Dilutions were made from this stock solution, and the highest concentration of DMSO in any solution was $0.01 \%(\mathrm{v} / \mathrm{v})$. Cell monolayers were inoculated with $2.5 \times 10^{5} \mathrm{RH}$ strain $T$. gondii tachyzoites. Two hours after inoculation, the medium was removed and replaced with maintenance medium containing ponazuril at concentrations of $0.1,1.0$, or 5.0 $\mu \mathrm{g} / \mathrm{ml}$ (Fig. 1). Control flasks received maintenance medium without ponazuril. Four flasks were used per ponazuril treatment dose. The TP assay was conducted after 4 days of treatment. The numbers of tachyzoites (mean of 16 counts/treatment [4 counts/flask]) present was determined by counting in a hemacytometer.

To determine when ponazuril acted on $T$. gondii, CV-1 cells were grown to monolayers on 22- $\mathrm{mm}^{2}$ glass coverslips in 6-well cell culture plates. The CV-1 cells were inoculated with $1 \times 10^{5}$ tachyzoites, and 2 hr later the media were removed and replaced with media containing 5 $\mu \mathrm{g} / \mathrm{ml}$ ponazuril. Replicate plates were treated with media containing $0.1 \%$ DMSO but no ponazuril. Coverslips were removed and examined $4,9,20,24$, and $48 \mathrm{hr}$ after the addition of ponazuril-containing medium or control medium. The number of parasites in 100 host cells was determined at each observation time.

The following procedure was used to determine whether ponazuril treatments killed $T$. gondii. After the medium was collected for the TP assay, the cell monolayer was rinsed twice with maintenance medium to wash off any residual ponazuril, and $5 \mathrm{ml}$ of maintenance medium was added to the flask. The flasks were then examined for 30 days for renewed growth of parasites, monolayer destruction, or both.

\section{Statistical analysis}

Mean tachyzoite counts were $\log$ transformed to stabilize variances before analysis and then back transformed for presentation. The MIXED procedure of SAS (SAS ver. 6.12, SAS Institute Inc., Cary, North Carolina) was used to perform analysis of variance. Tukey's honest significant difference $(P=0.05)$ was used to compare means.

\section{Mice and examination for Toxoplasma gondii}

For in vivo studies, a suspension of $50 \mathrm{mg}$ ponazuril per milliliter (lot 2161AA) was obtained from Bayer HealthCare Animal Health. This 


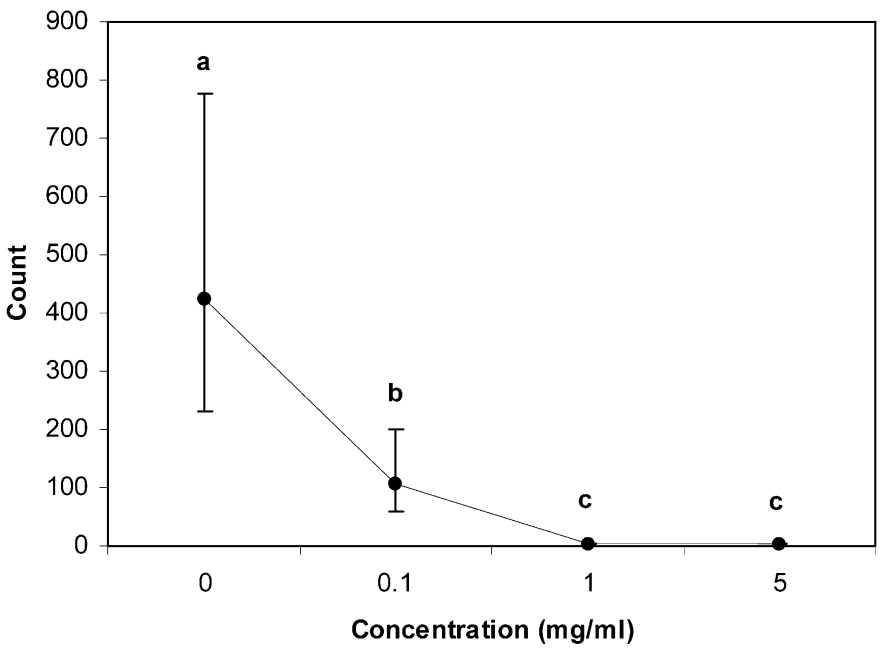

FIGURE 1. Activity of ponazuril against RH strain Toxoplasma gondii in CV-1 cell culture. Bars $=95 \%$ confidence intervals. Points with different letter are significantly different $(P<0.05)$ from each other.

suspension was diluted in distilled water and used for in vivo testing. Groups of 5 female CD-1 mice were used to determine the effects of treatment with ponazuril in the prevention and treatment of toxoplasmosis (Table I). All mice were inoculated subcutaneously in the dorsal scapular region with $1 \times 10^{3}$ tachyzoites. During the study, impression smears were made from the livers or lungs of any mice that died and were examined unstained by light microscopy for tachyzoites. At 8 wk postinoculation (PI), all surviving mice were bled from the retroorbita plexus. The serum was collected and examined for antibodies to $T$. gondii in a modified direct agglutination assay (MAT) (Dubey and Desmonts, 1987).

\section{Toxoplasma gondii polymerase chain reaction}

Brains were examined for $T$. gondii DNA using the primers described by Jauregui et al. (2001). The DNA was extracted from $0.5 \mathrm{~g}$ of brain tissue from mice in groups 3-9 (Table I) using a commercial DNA extraction kit (DNA Maxi Kit, Qiagen, Valencia, California). The purified DNA was diluted $1: 100$, and a $20-\mu l$ aliquot was taken and mixed with $200 \mu \mathrm{l}$ of InstaGene Matrix (Bio-Rad, Hercules, California). The samples were then incubated in a $56 \mathrm{C}$ water bath for $30 \mathrm{~min}$. The samples were vortexed and then placed in boiling water for $8 \mathrm{~min}$. The samples were vortexed and centrifuged in a microfuge for $2-3 \mathrm{~min}$. A $20-\mu 1$ aliquot of the supernatant was used per $50 \mu l$ polymerase chain reaction (PCR). The remaining supernatant was stored at $-20 \mathrm{C}$. PCR was performed on each sample using Ready To Go PCR Beads (Amersham Pharmacia Biotech Inc., Piscataway, New Jersey) and a Hybaid OmniGene thermocycler. The detection primers were based on the $T$. gondii ITS 1 sense primer 5'-GATTTGCATTCAAGAAGCGTGATAGTAT- $3^{\prime}$ and antisense primer 5'-AGTTTAGGAAGCAATCTGAAAGCACATC- $3^{\prime}$. Mouse $\beta$-actin was used as a positive control for DNA isolation and PCR (sense primer 5'-TCACCCACACTGTGCCCATCTACGA-3' and antisense primer 5' -CAGCGGAACCGCTCATTGCCAATGG-3'). Standard PCR reaction conditions were used with the following amplification parameters: $94 \mathrm{C}$ for $5 \mathrm{~min}, 35$ cycles at $94 \mathrm{C}$ for $1 \mathrm{~min}$, at $62 \mathrm{C}$ for $1 \mathrm{~min}$, at $72 \mathrm{C}$ for $1 \mathrm{~min}$, and at $72 \mathrm{C}$ for $10 \mathrm{~min}$. The PCR products were run on a $1 \%$ agarose gel.

\section{RESULTS}

\section{Effects on tachyzoite production}

There was a significant effect of ponazuril treatment $(P<$ $0.05)$ on tachyzoite production. Tukey's test indicated that the $1.0 \mu \mathrm{g} / \mathrm{ml}$ treatment was not significantly different $(P>0.05)$ from the $5.0 \mu \mathrm{g} / \mathrm{ml}$ treatment, but all other pairwise comparisons were significant $(P<0.05)$ (Fig. 1).

Host CV-1 cells treated with $5 \mu \mathrm{g} / \mathrm{ml}$ ponazuril contained only 4 parasites at observation times of $20 \mathrm{hr}$ or greater. The CV-1 cells that contained T. gondii and that were not treated had 8 or more tachyzoites at these observation times. Results of timed observations indicated that ponazuril inhibits $T$. gondii replication after the second division by endodyogeny approximately $20 \mathrm{hr}$ after treatment.

\section{Prevention of toxoplasmosis}

All nontreated mice developed acute toxoplasmosis and died or were killed $9-11$ days PI $(\bar{x}=10$ PI) (Table I). No mouse in group 3 or 4 given 10 or $20 \mathrm{mg} / \mathrm{kg}$ ponazuril 1 day before infection and then daily for 10 days died. None of the mouse developed acute toxoplasmosis after prophylactic treatments were stopped. Three of 5 mice in group 3 tested serologically positive for $T$. gondii using the MAT, and 1 of 5 mice in this group was positive by PCR on brain tissue (Fig. 2). All 5 mice tested serologically negative in the MAT in group 4 , and $T$. gondii DNA was not detected in the brains of these mice by PCR (Table I).

TABLE I. Protocol for evaluating the effects of ponazuril against Toxoplasma gondii in mice.

\begin{tabular}{clcc}
\hline Group & \multicolumn{1}{c}{ Treatment* } & No. mice/no. survived $\dagger$ & PCR $\neq$ \\
\hline 1 & Distilled water 3 days after infection & $5 / 0$ & ND $\$$ \\
2 & Distilled water 1 day before infection & $5 / 0$ & ND \\
3 & $10 \mathrm{mg} / \mathrm{kg}$ ponazuril 1 day before infection & $5 / 5$ & $5 / 1$ \\
4 & $20 \mathrm{mg} / \mathrm{kg}$ ponazuril 1 day before infection & $5 / 5$ & $5 / 0$ \\
5 & $10 \mathrm{mg} / \mathrm{kg}$ ponazuril 3 days after infection & $5 / 5$ & $4 / 1$ \\
6 & $20 \mathrm{mg} / \mathrm{kg}$ ponazuril 3 days after infection & $5 / 3$ & $5 / 5$ \\
7 & $10 \mathrm{mg} / \mathrm{kg}$ ponazuril 6 days after infection & $5 / 5$ & $3 / 3$ \\
8 & $20 \mathrm{mg} / \mathrm{kg}$ ponazuril 6 days after infection & $5 / 4 \|$ & $5 / 5$ \\
9 & $50 \mathrm{mg} / \mathrm{kg}$ ponazuril 6 days after infection & $4 / 1$ \\
\hline
\end{tabular}

\footnotetext{
* Mice in groups 1 and 2 never received ponazuril. Mice in groups 3 and 4 received ponazuril 1 day before and on the day of infection and then daily for 10 days.

Mice in groups 5-9 were treated daily for 10 days with ponazuril at the indicated day after infection.

$\dagger$ Number of mice inoculated/number of mice surviving infection.

$\ddagger$ Results of PCR; number tested by PCR on brain/number positive by PCR on brain.

$\S \mathrm{ND}$, not determined.

\| One mouse died in this group due to aspiration pneumonia.
} 


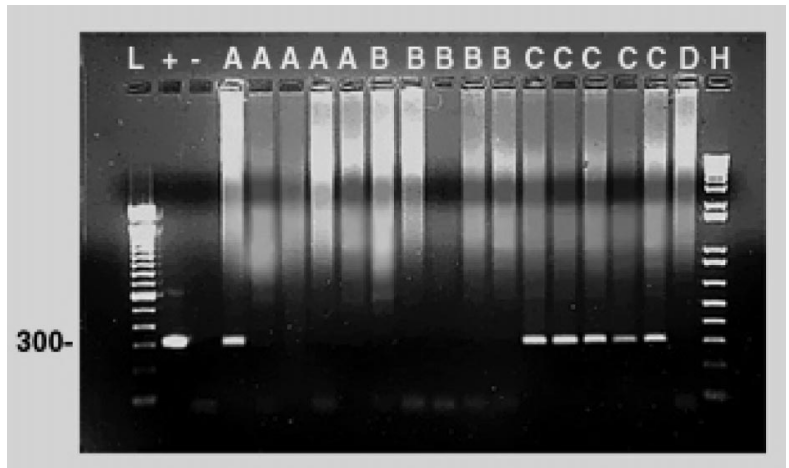

FIGURE 2. Results of Toxoplasma gondii ITS1 PCR on DNA from brains of mice infected with the RH strain of $T$. gondii and treated with ponazuril. (L) 100-bp ladder, (+) positive control T. gondii DNA, (-) negative control no DNA, (A) DNA from individual mice from group 3, (B) DNA from individual mice from group 4, (C) DNA from individual mice from group 6, (D) DNA from a mouse from group 9 and (H) $1 \mathrm{~kb}+$ ladder

\section{Treatment of acute toxoplasmosis}

All nontreated mice developed acute toxoplasmosis and died or were killed $9-11$ days PI $(\bar{x}=10 \mathrm{PI})$. Five of 5 mice $(100 \%)$ in group 5 and 5 of 5 mice $(100 \%)$ in group 6 were protected from fatal toxoplasmosis (Table I). All mice were serologically positive for $T$. gondii in groups 5 and 6 on the MAT. PCR was done on the brains of 4 mice in group 5 , and 1 was positive, whereas PCR was done on the brains of all mice in group 6, and they were all positive.

Three of 5 mice $(60 \%)$ in group 7 and 5 of 5 mice (100\%) in group 8 were protected from fatal toxoplasmosis. Deaths occurred on days 9 and $12 \mathrm{PI}$ in group 7. All 3 mice in group 7 and all 5 mice in group 8 tested serologically positive in the MAT. All group 7 and 8 mice tested positive for $T$. gondii by PCR. One of 5 mice in group 9 died 11 days PI. This mouse had aspiration pneumonia, and its death was probably not due to toxoplasmosis. The 4 other mice in group 9 survived until the end of the study. All surviving mice in group 9 were positive by the MAT. The brains of 4 mice in group 9 were examined by PCR, and 1 was positive. Relapse did not occur after treatments were stopped.

\section{DISCUSSION}

The present study demonstrates that ponazuril is effective in preventing and treating toxoplasmosis in mice. The lack of mortality and detection of $T$. gondii DNA in the brain of only 1 mouse treated prophylactically with $10 \mathrm{mg} / \mathrm{kg}$ and no mouse treated prophylactically with $20 \mathrm{mg} / \mathrm{kg}$ indicates that ponazuril is highly effective in the prevention of toxoplasmosis. Ponazuril at 10 or $20 \mathrm{mg} / \mathrm{kg}$ was also $100 \%$ effective in preventing mortality in mice with 3-day-old, established $T$. gondii infections but did not prevent the parasite from eventually reaching the brain in these mice as determined by PCR on brain tissue. Treatment of clinical toxoplasmosis at 6 days after infection was less effective with $10 \mathrm{mg} / \mathrm{kg}$ (60\% survival) than with 20 or $50 \mathrm{mg}$ / $\mathrm{kg}(100 \%$ survival; excluding 1 mouse in $50 \mathrm{mg} / \mathrm{kg}$ group that died of aspiration pneumonia).

Pyrimethamine alone or combined with sulfadiazine is the most commonly used treatment for human toxoplasmosis, whereas clindamycin and atovaquone are also frequently used (Luft and Chua, 2000). Ponazuril appears to be superior to clindamycin or atovaquone for the treatment of murine toxoplasmosis. Nikolic et al. (1999) found that treatment with 50 or 400 $\mathrm{mg} / \mathrm{kg}$ clindamycin hydrochloride in the feed daily for $3 \mathrm{wk}$ prevented mortality from the RH strain of $T$. gondii. Atovaquone given orally in the feed at $100 \mathrm{mg} / \mathrm{kg}$ for 14 days prevented death in $13 \%$ of the mice infected with the RH strain of $T$. gondii and examined by Djurkovic-Djakovic et al. (1999).

Diclazuril is a triazine anticoccidial related to ponazuril that has been evaluated against toxoplasmosis. Lindsay and Blagburn (1994) demonstrated that diclazuril prevented deaths from toxoplasmosis in 80 and $100 \%$ of mice treated 1 day before infection with 1 or $10 \mathrm{mg} / \mathrm{kg}$ diclazuril and then daily for 10 days after infection with RH strain of $T$. gondii. Lindsay et al. (1995) found that oral diclazuril at $10 \mathrm{mg} / \mathrm{kg}$ was 100 and $90 \%$ effective in preventing deaths in mice when given at 3 or 6 days, respectively, after infection with $\mathrm{RH}$ strain $T$. gondii. This activity is similar to that seen for ponazuril at $20 \mathrm{mg} / \mathrm{kg}$ in the present study.

\section{ACKNOWLEDGMENT}

S.M.M. was supported by a graduate student fellowship from Bayer HealthCare Animal Health.

\section{LITERATURE CITED}

BuZBy, J. C., AND T. RoberTs. 1996. ERS updates US foodborne disease costs for seven pathogens. Food Reviews 19: 20-25.

Djurkovic-Djakovic, O., T. Nikolic, F. Robert-Gangneux, B. Bobic, AND A. Nikolic. 1999. Synergistic effect of clindamycin and atovaquone in acute murine toxoplasmosis. Antimicrobial Agents and Chemotherapy 43: 2240-2244.

Dubey, J. P., And G. Desmonts. 1987. Serological responses of equids fed Toxoplasma gondii oocysts. Equine Veterinary Journal 19: 337-339.

Franklin, R. P., R. J. Mackay, K. D. Gillis, S. M. Tanhauser, P. E. GinN, AND T. J. KENNEDY. 2003. Effect of a single dose of ponazuril on neural infection and clinical disease in Sarcocystis neuronachallenged interferon-gamma knockout mice. Veterinary Parasitology 114: 123-130.

Gottstein, B., S. Eperon, W. J. Dai, A. Cannas, A. Hemphill, and G. GREIF. 2001. Efficacy of toltrazuril and ponazuril against experimental Neospora caninum infection in mice. Parasitology Research 87: 43-48.

Jauregui, L. H., J. Higgins, D. Zarlenga, J. P. Dubey, and J. K. LunNEY. 2001. Development of a real-time PCR assay for detection of Toxoplasma gondii in pig and mouse tissues. Journal of Clinical Microbiology 39: 2065-2071.

Jones, J. L., D. Kruszon-Moran, M. Wilson, G. McQuillan, T. Navin, AND J. B. MCAuley. 2001. Toxoplasma gondii infection in the United States: Seroprevalence and risk factors. American Journal of Epidemiology 154: 357-365.

, A. Lopez, M. Wilson, J. Schulkin, And Gibbs. 2001. Congenital toxoplasmosis: A review. Obstetrics and Gynecology Survey 56: $296-305$.

Lindsay, D. S., And B. L. Blagburn. 1994. Activity of diclazuril against Toxoplasma gondii in cultured cells and mice. American Journal of Veterinary Research 55: 530-533.

- AND J. P. DUBEY. 2000. Determination of the activity of diclazuril against Sarcocystis neurona and Sarcocystis falcatula in cell cultures. Journal of Parasitology 86: 164-166.

- , N. S. RipPey, AND B. L. Blagburn. 1995. Treatment of acute Toxoplasma gondii infections in mice with diclazuril or a combination of diclazuril and pyrimethamine. Journal of Parasitology 81: 315-318.

Luft, B. J., AND A. ChuA. 2000. Central nervous system toxoplasmosis 
in HIV pathogenesis, diagnosis, and therapy. Current Infectious Disease Reports 2: 358-362.

Mead, P. S., L. Slutsker, V. Dietz, L. F. Caig, J. S. Bresee, C. Shapiro, P. M. GRiffin, AND R. V. TAuXe. 1999. Food-related illness and death in the United States. Emerging Infectious Diseases 5: 607624.

Nikolic, T., O. Duurkovic-Djakovic, B. Bobic, A. Nikolic, and D. BABIC. 1999. Treatment protocol determines the efficacy of clin- damycin in acute murine toxoplasmosis. International Journal of Antimicrobial Agents 11: 145-149.

Roberts, T., AND J. K. Frenkel. 1990. Estimating income losses and other preventable costs caused by congenital toxoplasmosis in people in the United States. Journal of the American Veterinary Medical Association 196: 249-256.

SoAve, R. 2001. Prophylaxis strategies for solid-organ transplantation. Clinical Infectious Diseases 33: S26-S31. 